\title{
Cultural Identity and Human Rights: Minority Claims, Ethnic Identity and Group Rights
}

\author{
Dhruv Pande, Munmun Jha \\ Department of Humanities and Social Sciences, Indian Institute of Technology, Kanpur, India \\ Email: dpande@iitk.ac.in
}

How to cite this paper: Pande, D., \& Jha, M. (2016). Cultural Identity and Human Rights: Minority Claims, Ethnic Identity and Group Rights. Open Journal of Political Science, 6, 351-362.

http://dx.doi.org/10.4236/ojps.2016.64032

Received: July 25, 2016

Accepted: September 16, 2016

Published: September 19, 2016

Copyright $\odot 2016$ by authors and Scientific Research Publishing Inc. This work is licensed under the Creative Commons Attribution International License (CC BY 4.0).

http://creativecommons.org/licenses/by/4.0/

\begin{abstract}
This paper explores the relationship between cultural identity and human rights in the light of the dynamics of identity formation, based on the immediate external culture of any multicultural society. The objective of this study is to analyze the relationship between culture, identity and rights, which broadens the parameter of the existing dimension of human rights, using secondary sources to review the literature. It argues that these dynamics are marked by a number of factors and components featuring the group, community and individual rights. This prepares grounds for a wider, inclusionary and horizontal understanding of the Human Rights dimension and paradigms, not only in a multicultural society but also in a democratic nationstate which is significantly marked by minority rights and ethnic identity claims. Thus through a critical approach and a post-colonial perspective, this paper shows how this specific and particular dynamics of cultural identity casts an effect on the theory and practice of normative political theory and trajectories. The paper concludes that the Human Rights inherently invoke a challenge in the analysis of identity-formation and cultural heterogeneity dynamics, which are significant in the contemporary global democratic politics.
\end{abstract}

\section{Keywords}

Culture, Identity, Community, Recognition, Rights

\section{Introduction}

The conception of culture brings forth an inherent notion of "recognition". The struggles for recognition and the "dialogical phenomenon of recognition" underline a normative political theory. As Taylor (1992: p. 32) asserts: "Crucial feature of human life is its fundamentally dialogical character. We become full human agents capable of understanding ourselves, and hence of defining our identity, through our acquisition of rich 
human languages of expression". The struggles and the questions of identity are diverse and move towards a quest for a more "definitive-recognized" identity (Taylor 1989). Thus, identity politics can be seen in the light of an ongoing struggle as an inherent part of the process of democratic politics, in pursuance of fulfilling the credentials of the norms of recognition.

In order to discuss cultural identity and human rights, we would first like to locate the theoretical parameters of these concepts, while also draw attention to the terms used in this paper-culture, identity, recognition, and rights which play a significant role in the comparative public and private discourses.

\section{Culture: Basic Tools and Constituents}

Appiah (1994: p. 3) defines culture as the product of all "human work and thought". This conceptualization can lead us to re-think the political, social, and economic functioning of human beings in the society, and in further examining as to how "cultural identity" influences the discourse on human rights. According to Appiah (1994a: p. 134), collective identity "provide what we may call scripts: narratives that people can use in shaping their life-plans, and in telling their life stories".

Culture can be defined as a bearer of traditions and practices. What is its place in the context of a multicultural society? Does it need to be granted the space it demands? What is the basis of preference of one culture over the other? These are some of the questions that are addressed in this paper.

Traditions educate each other towards peaceful community building and bind the members of the community, and extend harmony beyond its frontiers. Therefore, we can locate the identity of a culture not only in its traditions and practices but also the effects that it bears upon the society. To understand culture, we must place it in a particularistic mode of expression. Each culture bears upon it, the historical traditions or legacy; it proposes some practices, which may or may not become institutionalized over a period of time. For instance, the social, political and economic history of a culture with respect to the cultural civilizations leading up to the development of modern nation-state results in an institutional or socially-abstract form of practices and traditions which sparingly create an effect on the contemporary culture of a community or a nation-state. Also, culture brings with it some forms of rights which are inherent in the individuals. These rights are tokens for individuals to exercise their well-being and to be part of the entire social paradigm in which they are located. For Parekh (2000: p. 152):

Even as culture shapes the economic, political and other institutions, it is in turn shaped by them. In their own different ways they structure the lived world, delimit the range of possible human activities and relations, give shape to fundamental human experiences, and profoundly influence the context and content of culture.

Culture imposes on the individual certain social duties or social obligations which become the common shared consciousness of all individuals within a culture. Kymlicka 
(1991: p. 3) deduces culture in relation to community:

What does it mean for people to 'belong' to a cultural community-to what extent are individuals' interests tied to, or their very sense of identity dependent on, a particular culture? And do people have a legitimate interest in ensuring the continuation of their own culture, even if other cultures are available in the political community.

To apply the mutuality outside one culture is the beginning of the problematic. We understand the differences between differently existing cultures and reach a position which is equally advantageous to all. That position is not absolute, but relative to the context. How to reach that position is one of the larger aims for creating an all-inclusive society.

\section{Identity, Identity Formation and Identity Politics}

Identity is a construct, based on economical, political, religious, ethnic and caste lines among others. In the Indian societal context for example, as part of the caste system, the so-called lower-most caste in the hierarchy, are known as the Dalits. They claim a separate identity as a result of age-long discrimination against them in the long history of Indian society; their struggles and resistances for equality have led to an identity politics of the Dalits, to the extent of setting up of national political parties expressing politically who Dalits are, within the Indian democratic framework. However, Guru (2001) argues that the Dalit identity not merely expresses who Dalits are, but also conveys their aspirations and struggle for change. Identity can be diverse, depending on the context with which it is associated. A person can have different identities at the same time. It can also vary according to the geopolitical conditions and the notion of time. Identity is not static; it changes according to the context making it a dynamic concept. It may be defined according to the socio-cultural and environmental factors that make up this identity. It is an additive phenomenon that builds up a consolidated identity: It is not just a summation of factors but a bringing together of differently existing contextual factors such as the societal milieu, economic upheavals, ethnic belongingness, religious connotation, etc. These features can be taken to be constitutive of a society or a community in which the identity is located. Every feature contributes to identity though there is a variance to which degree each exercises its influence.

Maclure (2003: p. 4) defines identity politics thus:

Identity Politics must be thought of not only as struggles for recognition, but also as games of disclosure and acknowledgement. Accordingly, when we try to articulate the meaning of contemporary identity politics using the Hegelian language of recognition, we can but conclude that these struggles over 'who we are' are means of enhancing self-respect and self-esteem (or dignity).

The use of identity in politics is many-fold. One of the prominent issues is the case where identity is misrepresented or under-represented. This gives rise to a need for using an identity claim on a political front to bargain for greater share in a power-sharing 
mechanism. Historically, this has led to the creation of separate states on the basis of linguistic identity or ethnic identity. Consequently, such demands pander to the tendency of generating separatist claims, leading to a more differentiated and decentralized democracy. As a response, a centralizing force for a unitary policy becomes relevant in such circumstances when matters of common concern desire a more transcendental, universal and cross-cutting solution. Hence identity works both, for the pros and the cons of a political system, especially in a democratic set-up. However in a totalitarian regime, the position of identity is often stifled leading to a homological identity, without the existence of or a suppressed existence of other varied and diverse identities.

The context of identity is highly relevant. Vajpeyi (2015) contends that "the same identity that is the basis of solidarity in one setting can become one's greatest vulnerability elsewhere." Thus there is an inherent contextuality to identity, where the societal conditions act and react upon the individual identity, lending it a dynamic character. This dynamic character of the individual identity is based on the recognition of one's identity by the "other", resulting in its "authenticity". Taylor (1992) mentions how the dynamics of identity contributes to its "authenticity," and how it is formed in contact with others. This brings together the two trajectories of culture and identity.

\section{Culture and Identity: Exploration of a Relationship}

The evolution of an identity is accompanied by the evolution of a culture. The cultural factors mould, shape and reshape an identity, which is an explicit and personified expression of a culture. It is a necessary part of human bearing, including the traditions which human beings bear upon themselves and the process of acculturation that assumes significance with respect to the need for reaching a compromise between the old inherent traditions and the newly acquired ones.

Gentile (2012: p. 10) links identity with violence, which for her is "complex". She further states, "it is necessary for a political theorist to handle these categories cautiously. It is possible to distinguish two key factors: the role of recognition on the one hand, and the idea of private interests and actions on the other". An identity is affected by the externality of culture at any given point of time and in any given context. The existing political culture of a state, for instance, affects the identity due to its features, say political participation, affecting the behavior of the new immigrants. Identity is modulated at this point of time by a number of factors that shape or remold this newly emerging identity. This leads to a consonance between the two-culture and identitythe complementarities of culture improvising the identity. Thus, emerges a direct relationship between the two. For example, in the context of contemporary India, Defetereos (2013: p. 112) explains: "While the Hindu right-wing within India has since received less favourable political results, the presence of a proto-Hindu nationalist cultural identity or Hindu majoritarian nationalism has not disappeared from the complexities of contemporary Indian political life".

This leads to a new identity, a reformulated one, which emerges in wake of cultural necessities. This is so because what culture propounds in theory, the identity performs 
in action. This also marks the beginning of a dialogical relationship between the two; it is "dialogical" in the Taylorian sense of this new identity entering into a dialogue or two-way communication with the new external culture. The effectiveness of this "dialogical relationship" is better understood through these entities i.e. culture and identity, recognizing each other's newly emerged capacities to interact and create a mutual set of complementarities towards the process of "acculturation" in a multicultural society. An identity becomes dynamic as culture lends it the features which make it durable not only in a particular context, but also across many contexts, making it transcendental. By being integral to culture, identity becomes more vibrant and diverse to ensure its long-term viability. Hence, a culture sustains itself as long as the societal demands find their usefulness with the existence of this particular identity.

Taylor (1989) provides us a political ontology that lays stress on the interactive component of individual identity-formation: In his Quebec example, Taylor does not make an assertion that French-Canadian culture develops and obtains its identity in dialogue with the Anglo-Canadian culture, and vice versa. Rather he implies that any identity-influencing interaction would be an intrusion upon French- Canadian cultural identity. Anglo-Canadian culture is treated as being abrasive to the French-Canadian self-determination. Creating individual identities is a different matter from preserving, protecting, or recognizing already-existing individual identities.

Bringing into focus the larger society, and throwing some light again on the question of multiculturalism and immigration, we see how this dialogical identity is applied to the context of a right to recognition: recognition of a single or multiple identities, in any form existing concretely or in its abstractness. According to Carens (1987: p. 251):

Borders should generally be open and that people should normally be free to leave their country of origin and settle in another, subject only to the sorts of constraints that bind current citizens in their new country. The argument is strongest, I believe, when applied to the migration of people from third world countries to those

of the first world.

Carens (2000) also contends that the expectations of immigrants in Quebec are morally defensible in the context of multiculturalism and equal opportunities. Macedo (1999) advocates the recognition of group rights. These perspectives lead us to the liberal thinking of co-existence and how equality can be guaranteed in its basic form and spirit to each and every citizen of a group in a society. However, the question of diversity within a group remains a challenge for the liberals, considering multiple differentiations.

\section{Culture, Identity and Rights}

Let us now seek to understand newly formed identity in terms of institutionalization. The relevant questions are: Why give this recognition in the form of institutionalization? What are the criteria of coding them? Which one shall we place above the other? How can they be applied in specific societies? In what aspects can they be applied in 
multicultural societies? How is their application viable?

There have been many debates and discourses on the rights in political philosophy. The history of these debates shows a division between the individualists and the communitarians. Fazal (2015: p. 10) states that, "The rights discourse in political philosophy has traditionally been polarised between the liberal-individualists foregrounding the unencumbered and abstract individuality and the communitarians arguing for the primacy of cultural constitution and social associations of the self". Among the communitarians, approaches are diverse in addressing the question of survival and preservation of different cultures. Taylor (1989) argues for a form of communitarianism, attaching intrinsic importance to the survival of different cultures. For Hegel (2001), cultural rights are the whole process of the actualization of the will. It is through this actualization that the will attains freedom. Thus, granting cultural rights actualizes the freedom condition in the individuals of that particular group.

Kukathas (1992) makes a direct assertion about the cultural health of ethnic minorities that seem to have suffered over the last decades. For him there is a need to lay emphasis on the fundamental importance of individual liberty or individual rights and question the idea that cultural minorities have collective rights. Groups change with the environment and shift with the political context, hence this is not sufficient basis for the granting of group rights. In fact, culture adds post facto content to a group identity. Also, collectives matter only due to individual's evaluations of a community or collectives. Furthermore, there is a prevalence of subgroup conflicts and internal differentiations in groups. So, even if cultural communities exist, they exist as voluntary associations. Hence, individuals should be "free to associate: to form communities and to live by the terms of those associations"; and it is this right of the individuals that gives a great deal of authority to the cultural communities. Thus, cultural groups are not "natural" but rather associations of individuals drawn together by history and circumstance and the group as such has no right to self-preservation or perpetuation, owing to its constantly changing dynamics. Jameson (1991: p. 12) asserts:

Whether the present is to be seen as a historical originality or as the simple prolongation of more of the same under different sheep's clothing-is not an empirically justifiable or philosophically arguable one, since it is itself the inaugural narrative act that grounds the perception and interpretation of the events to be narrated.

Kymlicka (1995) offers a defensive liberal theory which finds identity as being compatible with culture. He proposes special weight to cultural membership, and also equal citizenship. For him it is the cultural structures that provide the context of choice for an individual in that culture. Hence, group interests have their basis in liberal concerns about choice and equality. Hence it is the cultural rights that protect individual autonomy. Kymlicka states his primary aim is the need for the protection of the specific cultural "context" since the context allows individuals to exercise their own choice consistent with the liberal principles of equality. 


\section{Culture, Identity and Human Rights}

Amidst these debates on cultural identity, the notion of human rights emerges as a prominent discourse. Human rights can be seen as embodying the spirit of equal respect and dignity of all human beings and to safeguard and protect the cultural identity fabric discussed above. It is pertinent to protect and safeguard the dignity of all human beings, especially in their capacity of adapting to the changing and shifting contexts. This marks a beginning of the growth of the human rights network, not only at the local level but also a global one.

With respect to the UN Declaration of Human Rights, Ishay (2004) says:

Conflicting political traditions across the centuries have elaborated different visions of human rights rooted in past social struggles. That historical legacy and current conflicting meanings of human rights are...all reflected in the structure and substance of this document...It also draws on the historical record in order to identify and clarify several misconceptions that persist both within and outside the human rights community today.

We argue for a cultural identity, which is dynamic, more than just "dialogical" or "authentic", and consonant with an alternative understanding of human rights. Hegel's "right" finds its complementarity with cultural identity in two of the theoretical conjectures: 1) the dialectics, and 2) actualization of the will.

For Hegel (2001), what is rational is real and what is real is rational. This sows the seed for an interaction between the identity a person inheres and his immediate contact with the outer world; the inner self being the rational and the outer world being the real. The right is positive as it finds its expression in the law and has validity in the state. The origin of this right is in the will which is something infinite and blank and gains its actualization through the reality when it gets a definitive character through its exposure to the outer world. It is the subjective will which is now seen as actual freedom and hence the cultural identity acquires a particularistic subjective character, as opposed to the objectively existing one.

Baxi (2002) questions whether identities get universalized all over again in positing a universal bearer of human rights, obscuring the fact that identities may themselves be vehicles of power. There are two primary facets of his discourse on human rights: 1) suffering, and 2) resistance. It is through these two aspects that he puts forth a case for more justifiable human rights, the "contemporary" human rights. Suffering is a centre stage for an understanding of human rights. He thus invokes a "bottom-up" approach. The viability and productivity of the existing human rights can be seen from the viewpoint of those who "suffer" rather than granting rights in a vacuum. This points to a relation between dynamic cultural identity and the discourse on contemporary human rights, laying grounds for reverting the theory of the continuous, imposed, hegemonic institutional decision-making, and bringing forth a more widespread, acceptable, and a viable concept of human rights that is more humanized and people-friendly. Bhargav (1995) attempts to explain the intersection of religious and secular identities. He begins 
with a definition of identity and ends by asserting that despite a popular belief, secularism and religion (and the identities people have relating to them) are not always incompatible.

For Kapur (2006) revisiting the colonial encounter is critical in order to understand the limitations and possibilities of human rights in the contemporary period. It is essential for human rights advocates to embrace this history. Assertions about the universality of human rights simply deny the reality of those whom it claims to represent and speak for, disclaiming their histories and imposing another's through a hegemonizing move. Thus, the liberal tradition from which human rights have emerged not only incorporates arguments about freedom and equal worth but it also incorporates arguments about civilization, cultural backwardness, and racial and religious superiority. Furthermore, human rights remain structured by this history. Hence we need to move beyond debates between the universal character of human rights and their historical particularity. Also there needs to be a reorientation in human rights scholarship and education. Human rights advocates, including feminist scholars, have failed to adequately centre and interrogate the colonial trappings and First World hegemonic underpinnings of this project, and frequently ignore or exclude the non-West from the conversation. Analyzing human rights from a postcolonial perspective provides an enriched perspective of how the terrain has operated and the politics of inclusion and exclusion that it has sustained and even justified.

Kapur (2006) unpacks three normative claims on which the human rights project is based and exposes the "dark side" of this project. She examines the larger context within which human rights has taken shape, and critiques the claim that human rights is a part of modernity's narrative of progress; interrogates the assumption that human rights are universal, challenging its neutral and inclusive claims; and unpacks the liberal subject on which the human rights project is based.

This briefly leads us to think of this discourse of human rights from a critical perspective highlighting as to how the importance of a context assumes significance. The context here refers to a simple analytical trajectory of how human rights can come from "below," how they can be grounded on a more democratic ground and how they can be more widely based on more wide-ranging concerns of human capacities, rather than just being reflective of a single, homogenous and a hegemonic discourse, which is, a discourse of the West. Carens (2000) makes a case for a contextual understanding lending it a vivid character as even a closer attention to context will lead to a richer, more complex, and ultimately more satisfactory theoretical account of the ideal of evenhandedness.

Taylor (1992) examines two different approaches to the politics of equal recognition: the politics of universal dignity, which originate from the collapse of social hierarchies, the basis for old concept of "honor" and the politics of difference which has its origin from the notion of individualized identity which we call "authenticity". There is a conflict between "the politics of universal dignity" and "the politics of difference": while the former supports non-discrimination through being difference-blind, the latter believes that the value of any different identity is equal and different identities deserve equal 
recognition, but not necessarily equal treatment. These approaches result in the idea of what we call "multiculturalism".

Kymlicka (1995) believes that there are two broad patterns of cultural diversity: 1) National minorities who wish to remain as distinct societies alongside the majority culture, and demand various forms of autonomy or self-government to ensure their survival as distinct societies because their culture incorporates the previously self-governing, territorially concentrated cultures into a larger state, for example the Frenchspeaking Quebecois in Canada show strong territorially concentrated and self-governing claims while at the same time remain distinct societies alongside the majority Anglo-Saxon culture; and 2) Ethnic groups, whose culture arises from individual and familial immigrations and who wish to integrate into the larger society, and to be accepted as a full member, for example in Fiji Islands, a large number of diverse ethnic groups constitute the present population as the most cosmopolitan of all South Pacific nations. There are three important ways in which democracies have responded to the demands of national minorities and ethnic groups. First, in most multination states, the component nations are inclined to demand the self-government rights, a form of political autonomy or territorial jurisdiction, so as to ensure the full and free development of their cultures and the best interests of their people. Second, immigrant groups demand the poly-ethnic rights which intend to help ethnic groups and religious minorities express their cultural particularity and pride without hampering their success in the economic and political institutions of the dominant society. Third, national minorities, ethnic groups and other non-ethnic social groups are increasingly interested in the idea of special representation rights which are often defended as a response to some systemic disadvantage or barrier in the political process which makes it impossible for the group's views and interests to be effectively represented.

Multination states are formed by absorption, often of indigenous groups that share a language and are granted distinct rights or claims to language and land within the given territory. This is in contrast to polyethnic states, which normally have a non- homogenous citizenry and large immigrant populations that usually speak the dominant language of the state in which they reside. These groups often band together to remain distinct from the hegemonic culture of the state. Kymlicka (1995) identifies three ways in which minority groups ensure the accommodation of distinct group rights. These measures are, "self-government rights", "polyethnic rights" and "special representation rights".

\section{Conclusion: Implications for Cultural Identity and Multiculturalism}

In view of the above-mentioned debates and examples, we would like to conclude in the framework of multiculturalism. The recognition of differences based on identity is an integral part of multiculturalism. As Miller (2008) states: "The intense desire of the migrants to make a better life for themselves (often against the background of intolerable conditions in their home countries) combines with the economic needs of public and 
private sector employees in the receiving states to defeat populist agitation for highly restrictive immigration controls". This is symptomatic of the process of immigration, especially when we figure out the dimension of dynamic identity based on the immediate external culture.

Taylor (1992) articulates a pro-multiculturalists argument and points out that the multiculturalists' thesis centers on misrecognition. He examines how identity recognition has become a vital human need. Taylor believes we construct our personal identity through dialogue with ourselves and with others. In practical terms, recognizing differences in modern states means ending discrimination in these states. Thus, this Taylorian analysis fits into the multicultural society based on the principles of recognition and authenticity; it implies a social construct of this dynamic identity resulting in a less-discriminatory policy decision-making in the modern states through identifying and recognizing cultural diversity.

This leads to a diversified variety of group rights in a multicultural society, which can also be termed as the collective rights. Parekh (2000: p. 213) states that these can be acquired in one of the two ways: 1) derivative collective rights occur when individuals pool their rights together or alienate them to the collectivity; 2) primary collective rights are sui generis by virtue of being what they are and not derivatively from their members.

To summarize the theoretical discourses, paradigms and debates on the recognition of cultural groups and minorities, a comparative analogy can be drawn between Taylor and Kymlicka from a critical perspective. Taylor (1992) focuses too much on the cultural side of recognition, while failing to take into account the socio-economic implications that distinct cultural minorities often face. Indeed, while he does not share this view, Kymlicka asserts that opponents to multiculturalism argue that it ghettoizes minorities and impedes their integration into mainstream society. So, both Kymlicka (1995) and Taylor (1992) leave out questions of gender, sexual orientation, race and class thus ignoring the intersectional forms of discrimination that many immigrants face.

Kymlicka (1992) argues that there are two modes of incorporation of minority groups, each of which entails different legitimate claims and corresponding political solutions. Kymlicka's recognition does not derive from the equal worth of cultures that would be depreciated if not granted proper acknowledgement. Rather recognition is based on political relations of cultural groups to the larger society, since it is the political relation of each group separately to the state which acclaims worth of that cultural group in the form of cultural membership, as for Kymlicka. Both Taylor (1989) and Kymlicka (2002) address questions of political and cultural rights in their discussion of recognition, which is symptomatic of a tendency in society to make the "struggle for recognition" a significant form of civil strife in our times.

Finally, in conclusion, we suggest that a dynamic view of cultural identity is morally valid. It combines the philosophical principles and its practical implications. The ethical-moral dimension is well stated by Nagel (1995) who thinks of rights as aspects of 
status, part of what is involved in being a member of the moral community. The idea of rights expresses a particular conception of the place that should be occupied by individuals in a moral system. It is a universal normative condition, consisting of what is permitted to be done to persons, what persons are permitted to do, what sorts of justifications are required for preventing them from doing what they want. This opens the path for further exploring the individual identity in a moral community. It is this moral dimension which justifies the cosmopolitan identity in the framework of multiculturalism.

\section{Acknowledgements}

This paper is partly based on Dhruv Pande's doctoral dissertation titled, "The Dynamic Notion of Cultural Identity: Implications for Human Rights", submitted to the LUISS Guido Carli University, Rome, Italy in 2012, supported by the Confederation of Italian Industries. Many thanks are due to Sebastiano Maffettone and Aakash Singh Rathore for their valuable support.

\section{References}

Appiah, K. A. (1994). Identity against Culture: Understandings of Multiculturalism (pp. 1-52). Occasional Paper Series, Berkeley: University of California Press.

Appiah, K. A. (1994a). Race, Culture, Identity: Misunderstood Connections (pp. 53-136). The Tanner Lectures on Human Values, San Diego: University of California.

Baxi, U. (2002). The Future of Human Rights. New Delhi: Oxford University Press.

Bhargav, R. (1995). Religious and Secular Identities. In U. Baxi, \& B. Parekh (Eds.), Crisis and Change in Contemporary India (pp. 317-349). London: Sage Publications.

Carens, J. H. (2000). Culture, Citizenship and Community: A Contextual Exploration of Justice as Evenhandedness. Oxford: Oxford University Press. http://dx.doi.org/10.1093/0198297688.001.0001

Carens, J. H. (1987). Aliens and Citizens: The Case for Open Borders. In The Review of Politics (pp. 251-273). Cambridge: Cambridge University Press. http://dx.doi.org/10.1017/s0034670500033817

Defetereos, C. (2013). Ashis Nandy and the Cultural Politics of Selfhood. New Delhi: Sage Publications.

Fazal, T. (2015). Nation-State and Minority Rights in India: Comparative Perspectives on Muslim and Sikh Identities. London: Routledge.

Gentile, V. (2012). From Identity-Conflict to Civil Society: Restoring Human Dignity and Pluralism in Deeply Divided Societies. Rome: Luiss University Press.

Guru, G. (2001). The Language of Dalit-Bahujan Political Discourse. In G. Shah (Ed.), Dalit Identity and Politics (pp. 97-107). New Delhi: Sage Publications.

Hegel, G. W. F. (2001). The Philosophy of Rights (S. W. Dyde, Trans.). Kitchener, Ontario: Batoche Books.

Ishay, M. R. (2004). What Are Human Rights? Six Historical Contoversies. Journal of Human Rights, 3, 359-371. http://dx.doi.org/10.1080/1475483042000224897

Jameson, F. (1991). Postmodernism or The Cultural Logic of Late Capitalism. Durham: Duke University Press. 
Kapur, R. (2006). Human Rights in the $21^{\text {st }}$ Century: Take a Walk on the Dark Side. Sydney Law Review, 28, 665-687.

Kukathas, C. (1992). Are There Any Cultural Rights? Political Theory, 20, 105-139. http://dx.doi.org/10.1177/0090591792020001006

Kymlicka, W. (1991). Liberalism, Community and Culture. Oxford: Oxford University Press.

Kymlicka, W. (1992). The Rights of Minority Cultures: Reply to Kukathas. Political Theory, 20, 140-146. http://dx.doi.org/10.1177/0090591792020001007

Kymlicka, W. (1995). Multicultural Citizenship: A Liberal Theory of Minority Rights. Oxford: Oxford University Press.

Kymlicka, W. (2002). Contemporary Political Philosophy: An Introduction. Oxford: Oxford University Press.

Macedo, S. (1999). Deliberative Politics: Essays on Democracy and Disagreement. Oxford: Oxford University Press.

Maclure, J. (2003). The Politics of Recognition at an Impasse? Identity Politics and Democratic Citizenship. Canadian Journal of Political Science, 36, 3-21. http://dx.doi.org/10.1017/s0008423903778500

Miller, D. (2008). Immigrants, Nations and Citizenship. The Journal of Political Philosophy, 16, 371-390. http://dx.doi.org/10.1111/j.1467-9760.2007.00295.x

Nagel, T. (1995). Personal Rights and Public Space. Philosophy and Public Affairs, 24, 83-107. http://dx.doi.org/10.1111/j.1088-4963.1995.tb00024.x

Parekh, B. (2000). Rethinking Multiculturalism: Cultural Diversity and Political Theory. Harvard: Harvard University Press.

Taylor, C. (1989). Sources of the Self: The Making of the Modern Identity. Harvard: Harvard University Press.

Taylor, C. (1992). The Politics of Recognition. In A. Gutmann (Ed.), Multiculturalism and the Politics of Recognition (pp. 25-74). Princeton: Princeton University Press.

Vajpeyi, A. (2015). The Prison House of Identity. New Delhi: The Hindu. www.thehindu.com/opinion/lead/dimapur-lynching-the-prison-house-of-identity/article69911 $\underline{76 . e c e}$

Submit or recommend next manuscript to SCIRP and we will provide best service for you:

Accepting pre-submission inquiries through Email, Facebook, LinkedIn, Twitter, etc.

A wide selection of journals (inclusive of 9 subjects, more than 200 journals)

Providing 24-hour high-quality service

User-friendly online submission system

Fair and swift peer-review system

Efficient typesetting and proofreading procedure

Display of the result of downloads and visits, as well as the number of cited articles

Maximum dissemination of your research work

Submit your manuscript at: http://papersubmission.scirp.org/ 